ӘӨЖ671(01)

МРНТИ 03.02.09

https://doi.org/10.51889/2021-3.1728-5461.08

\author{
${ }^{1}$ Ishmukhamedov Sharip*, ${ }^{2}$ Kassenov Farkhad \\ ${ }^{1}$ associate professor, candidate of political sciences \\ "Turan" University \\ ${ }^{2}$ Phd student, Institute of Philosophy, Political science and Religious studies \\ of the CS MES RK
}

\title{
FEATURES OF DIGITALIZATION OF POLITICAL PROCESSES IN KAZAKHSTAN
}

\begin{abstract}
The digitalization process in Kazakhstan has its own brief history, achievements and results, which are noticed at the level of the UN, the World Bank and other international rating organizations. The most interesting is the process of digitalization of the political sphere in Kazakhstan, which can be considered a completely new process and trend. It is for the first time manifested and discussed in Kazakhstan in comparison with other countries of the Central Asian region. Theoretical studies show that digitalization of the political sphere has the main directions as "digital democracy", "digital bureaucracy" and "digital diplomacy". The modern example of Kazakhstan shows that the digitalization of the political sphere is developing and strengthening. This is directly related to the development of Internet technologies, the availability of the Internet, the growth of the political culture of population. The political power in Kazakhstan pays attention to several directions of process of digitalization of the political sphere. However, there is no clear and unambiguous choice between the options for supporting "digital bureaucracy" or "digital democracy". The latest processes and tendencies in the actions of officials, deputies of Kazakhstan related to the adoption of new laws on "media", on "social networks" show that there is a search for administrative, legislative ways and methods of managing and control of the process of politicizing social networks.
\end{abstract}

Key words: digitalization, Kazakhstan, opposition, social networks, political process.

${ }^{1}$ Иимухамедов Шарип*, ${ }^{2}$ Касенов Фархад

${ }^{1}$ кандидат политических наук, дочент, университет Туран

E-mail:sharipkz@mail.ru

${ }^{2}$ докторант Института философии, политологии и религиоведения МОН РК

\section{ОСОБЕННОСТИ ЦИФРОВИЗАЦИИ ПОЛИТИЧЕСКОГО ПРОЦЕССА В КАЗАХСТАНЕ}

\section{Аннотаичи}

Процесс цифровизации в Казахстане имеет свою короткую историю, достижения и результаты, которые замечают на уровне $\mathrm{OOH}$, Всемирного банка и других международных рейтинговых организаций. Наиболее интересным является процесс цифровизации политической сферы в Казахстане, который можно считать совершенно новым процессом и тенденцией. Он впервые проявляется и обсуждается в Казахстан в сравнении с другими странами региона Центральной Азии. Теоретические исследования показывают, что цифровизация политической сферы имеет основные направления как «цифровая демократия», «щифровая бюрократия» и «щифровая дипломатия». Современный пример Казахстана показывает, цифровизация политической сферы развивается и усиливается. Это напрямую связано с развитием интернет технологий, доступностью интернета, ростом политической культуры населения. Политическая власть в Казахстане уделяет внимание нескольким направлениям процесса цифровизации политической сферы. Однако нет четкого 
и однозначного выбора между вариантами поддержки «цифровой бюрократии» или «цифровой демократии». Последние процессы и тенденции действий чиновников, депутатов Казахстана связанных с принятием новых законов о «СМИ», о «социальных сетях» показывают наличие такого поиска. Таким образом, можно утверждать, что происходит поиск административных, законодательных путей и методов управления процессом политизации социальных сетей.

Ключевые слова: цифровизация, Казахстан, оппозиция, социальные сети, политический процесс.

\author{
${ }^{1}$ Иимұхамедов Шәріп *,2 Касенов Фархад \\ ${ }^{1}$ Саяси вылымдардың кандидаты, доиент \\ Тұран университеті, Қазақ̧стан Республикасы \\ E-mail:sharipkz@mail.ru \\ ${ }^{2}$ философия, саясаттану және дінтану институтының докторанты \\ КР БҒM
}

\title{
ҚАЗАҚСТАНДАҒЫ САЯСИ ПРОЦЕСТІ ЦИФРЛАНДЫРУ ЕРЕКШЕЛІКТЕРІ
}

\section{Аң̧датпа}

Қазақстандағы цифрландыру процесінің өзінің қысқаша тарихы, жетістіктері мен нәтижелері бар, олар БҰҰ, Дүниежүзілік банк және басқа да халықаралық рейтингтік ұйымдар деңгейінде байқалады. Ең танымалы сұрағы ол - Қазақстандағы саяси саланы цифрландыру процесі, оны мүлде жаңа үрдіс пен үдеріс деп санауға болады. Бұл Орталық Азия аймағының басқа елдерімен салыстырғанда Қазақстанда алғаш рет көрініс тауып, талқылануда. Теориялық зерттеулер саяси саланы цифрландырудың «цифрлық демократия», «цифрлық бюрократия» және «цифрлық дипломатия» сияқты негізгі бағыттары бар екенін көрсетеді. Қазақстанның қазіргі үлгісі саяси саланы цифрландыру дамып, нығайып келе жатқанын көрсетеді. Бұл Интернет-технологиялардың дамуына, интернеттің қолжетімділігіне, халықтың саяси мәде-ниетінің өсуіне тікелей байланысты. Қазақстандағы саяси билік саяси саланы цифрландыру процесінің бірнеше бағыттарына назар аударады. Дегенімен, «цифрлық бюрократияны» немесе «цифрлық демократияны» қолдау нұсқаларының арасында нақты және біркелкі таңдау жасалынбаған. Қазақстандық шенеуніктердің, депутаттардың «БАҚ», «әлеуметтік желілері» туралы жаңа заңдарды талқылап, қабылдауға байланысты әрекеттеріндегі соңғы процестер мен тенденцияларды талдап түсіндіретіні - ол, әлеуметтік желілердің саясаттандыру процесін басқарудың әкімшілік, заңнамалық жолдары мен әдістері іздестіріліп жатқанын көрсетеді.

Kiлm сөздер: цифрландыру, Қазақстан, оппозиция, әлеуметтік желілер, саяси процесс.

Introduction

Digitalization of the work of public service, economic processes, business through electronic government, social networks, access to mobile communications are among the main and important tasks for every modern state and society. According to modern research, digital technologies penetrate into various spheres of social, economic, political relations, allowing the population to expand the possibilities of governance, development of the state and society. However, the most difficult thing is the digitalization of the political sphere for the development of democratization processes, openness of government decision-making, and increased accountability of government bodies for decisions and actions.

The relevance of the article is determined by the growth of the digitalization process in various areas of public relations in Kazakhstan, as well as in the entire region of Central Asia. Especially important is the need for a scientific assessment of the process of digitalization of the political sphere, political relations within society, in relation to political actors. There is a constant increase in the quality of the Internet, the availability of Internet technologies and the role of social networks in the 
public, economic and political spheres in Kazakhstan. Recent discussions on the role of social media show the desire of authorities to give direction to this process and identify barriers to its influence in society. Obviously, one can expect further legislative, administrative decisions for choosing a direction, methods of controlling the process of politicizing social networks, determining the role of social networks, digital media. In these conditions, one can expect an increase in conflicts in the context of the growing role of social networks in society, their popularity among young people and politically active citizens.

The aim of the study is an attempt to prove that at the level of government in Kazakhstan there is a process of choosing between two main ideas and points of view in relation to the process of politicization of social networks, politicization of the Internet space. The objectives of the study are to study the process of politicization of social networks, the Internet space in Kazakhstan, as well as the attitude of the country's authorities to this process. The prospect of politicization of the Internet space in the Central Asian region is also assessed in connection with the growth of general digitalization, access to the Internet in society.

Research methods. The goal of achieving the objectivity of the results of scientific research required the use of comparative analysis, case study, functional analysis, as well as factual analysis of the conclusions and data of international organizations on the topic of digitalization in Kazakhstan and Central Asian countries.

Sources of research.

The objectivity of the conclusions is based on the widespread use of modern and relevant materials and data from international organizations, the opinions and positions of well-known scientists and authors studying the process of digitalization and politicization of the Internet space, social networks. Materials and data from the media and other open sources about the facts and processes of digitalization of political sphere, Internet space in modern Kazakhstan were also used.

Main part.

Modern studies of digitalization processes in the CIS countries show that there is a certain trend in the development and use of digital technologies. According to the opinion of the Russian scientist Konkov A.E. modern digitalization practice shows that three most significant areas of digitalization of political relations between citizens and state bodies are manifested: First, digital democracy, which introduces new information and communication technologies for accounting, studying the opinion of the population in relation to the decisions made by the authorities. Secondly, technologies of "e-government" for increasing competence, fast responses to ruling authorities, state bodies, which also includes the ability of the population to send their requests directly to executive bodies and services within the framework of the concept of "digital bureaucracy". Thirdly, digital diplomacy, which uses modern digital technologies to promote the political goals of the ruling class, not only within the country and society, but also in international relations [1].

Theoretical studies of the digitalization of the political sphere, political relations between the government and society, the opposition, the media confirm that there is a deep transformation of traditional forms, methods of cooperation, relations between the main actors, participants in political relations. Digitalization, social networks, accountability and transparency will become the main drivers of new forms and levels of relations between the authorities, officials, the government and the opposition, civil society, and the politically active population. But it is confirmed that in the context of different political regimes, systems, the depth of digitalization, the level of education of the population, the political culture of society, there will be different results of digitalization in the political sphere. In general, the world practice of research shows that the main result of digitalization carried out by the authorities themselves, the government "from above" is the development of mechanisms for the work of the state apparatus itself, improving the quality of work, expanding the functions of state bodies within the framework of e-government [2]. The researchers also add that along with the development of e-government, the digitalization of the work of the state bodies themselves, the entire system of relations between the authorities, the opposition, the population and the media will change. Digitization, the spread of digital technologies, the politicization of social networks will completely change the mechanisms of work of the media, political parties, and the 
opposition. As a result, this will lead to the emergence and success of digital parties, digital media, the emergence of new "digital media leaders" who will eventually replace traditional media, traditional political parties and leaders. Attempts by the authorities to prohibit the activities and development of digital political actors will not be successful in the context of globalization, digitalization and digital education and the experience of the population [3]. Thus, theoretical studies confirm that, ideally, political digitalization in should be aimed at the further development of democracy, accountability of the authorities in the decision-making process, reporting of state bodies, and vice versa, digitalization without education, without educating the population, developing people's experience will have the opposite the effect. Digitalization, which does not include electronic voting, electronic applications and petitions of citizens, special political educational programs for the population, special platforms for discussing the activities of parliament, government, local authorities, will be limited and ineffective in the political sphere [4].

It is important to note that at the state level in Kazakhstan it is recognized that digitalization is one of the most important mechanisms for solving not only large-scale national tasks of economic development, strengthening business, but also a tool for solving structural problems in the fight against corruption, increasing the accountability of state bodies, and more. Modern achievements and experience of Kazakhstan in the implementation of the national program for expanding Internet access, increasing Internet speed, developing e-government and civil service also confirm that digitalization has a positive effect on the overall development of the quality, efficiency of public services and public service. In his statement in 2021, the head of the Anti-Corruption Agency of the Republic of Kazakhstan, Alik Shpekbayev, confirmed that digitalization has become the most effective mechanism for combating corruption in the civil service [5]. Speaking about the connection between digitalization and the effectiveness of the fight against corruption in the country, one can analyze the research results of the most famous international governmental and non-governmental organizations, such as the World Bank and Transparency International. Modern data from international organizations confirm that there is a connection and mutual influence of the level of development, the depth of the spread of digitalization in public service and the results of the fight against corruption. According to the latest official data from the World Bank website and the World Bank's own index on digitalization "Digital Adoption Index", Kazakhstan has achieved great success and results in the process of digitizing the work of the civil service to help the population, business, and economy. According to the World Bank website, DAI is a universal index that measures countries' digital development, spread of digital tech in economy, society where three dimensions are compared and calculated most: digital tech for people, government, and business. The DAI index includes only 180 countries according to the latest calculations and studies of 2014 and 2016 [6]. It is interesting to compare the data and results of studies of the level of digitalization, achievements of the fight against corruption in different countries, especially in the CIS region (see Table 1). Based on the results of studying the achievements, successes of countries in terms of the level of fighting corruption according to the "Corruption perception index" by Transparency International INGO, some preliminary conclusions can be drawn, which can be seen from Table 1 [7]. In addition, for the objectivity of the conclusions, data on the level of digitalization in countries can be cited according to the results of a study by the Institute for Management and Development. The rating of the Institute is the most famous and objective in the field of studying the level and success of digitalization by scientists, professionals, government agencies, since it is based not only on official data provided by government agencies of the studied countries, but also on data from NGOs, international organizations and opinion polls of local businesses. It is important to highlight that the rating and research of the Institute includes information on only 63 countries, where the CIS region was represented only by Kazakhstan, Russia and Ukraine. The rating lacks information on the situation in Uzbekistan, Kyrgyzstan and other CIS countries [8]. Comparison of data from Transparency International, Institute for Management and Development and the World Bank on digitalization and corruption in countries shows that there is a clear, demonstrable link between these two variables and processes. The data presented show that the successes and achievements of digitalization of public administration, service, business directly affect the effectiveness of the fight against corruption. Thus, 
digitalization as a process and goal of state, social development should continue and develop in the field of politics and political relations, as the most important area for strengthening democratization, openness and stability of the state and economy. Digitalization cannot be limited only to egovernment, the development of the work of a bureaucratic decision-making mechanism.

Table 1: Comparative indicators of the ranking/ achievements of countries by the level of digitalization and the fight against corruption

\begin{tabular}{|c|c|c|}
\hline $\begin{array}{l}\text { Rank/position of the country } \\
\text { according to the «World digital } \\
\text { competitiveness ranking» of the } \\
\text { IMD in } 2020 \text { (latest official } \\
\text { raking by } 20.08 .2021 \text { ) }\end{array}$ & $\begin{array}{l}\text { Rank of the country according } \\
\text { to the «Corruption perception } \\
\text { index» by Transparency } \\
\text { International in } 2020 \text { (latest } \\
\text { official ranking by } 20.08 .2021 \text { ) }\end{array}$ & $\begin{array}{l}\text { Rank of the country according } \\
\text { to the «Digital Adoption Index» } \\
\text { of the WB in 2014/2016 (latest } \\
\text { official raking by 20.08.2021). }\end{array}$ \\
\hline The USA \#1 & The USA \#25 & The USA $-72 / 74 \%$ \\
\hline Singapore \#2 & Singapore \#3 & $\begin{array}{l}\text { Singapore } 87 / 88 \% \text { - leading } \\
\text { position in the ranking }\end{array}$ \\
\hline Denmark \#3 & Denmark \#1 & Denmark $77 / 79 \%$ \\
\hline Sweden \#4 & Sweden \#3 & Sweden $80 / 83 \%$ \\
\hline Switzerland \#6 & Switzerland \# 3 & Switzerland 79 / 82\% \\
\hline The Netherlands \#7 & The Netherlands \#8 & The Netherlands $82 / 83 \%$ \\
\hline Kazakhstan \#36 & Kazakhstan \#94 & Kazakhstan 63/67\% \\
\hline Russia \#43 & Russia \#124 & Russia 68/74\% \\
\hline Ukraine \#58 & Ukraine \#117 & Ukraine $43 / 45$ \\
\hline Uzbekistan - no data & Uzbekistan \#146 & Uzbekistan 30/40\% \\
\hline $\begin{array}{l}\text { Venezuela \#63 (the last in the } \\
\text { ranking) }\end{array}$ & Venezuela \# 176 & Venezuela $-49 / 49 \%$ \\
\hline
\end{tabular}

Source: Prepared by the author based on data from the World Bank [6], Transparency International INGO [7], Institute for Management and Development [8].

The trend of digitalization grows in social, business spheres and it is common for the region of Central Asia as a part of world community and information communications. Digitalization of political processes are most pronounced in Kazakhstan, which is the most developed country in terms of the penetration of communicative technological innovations deep into the public organism among all the countries of Central Asia. This is due to the quantitative and qualitative parameters of spread of information-communication technologies, internet access and information freedoms of the people. So, the number of smartphone users is growing from year to year, and now it is quite comparable with the average values of developed countries. According to the World Bank, it is possible to compare statistics of the number of mobile cellular subscriptions per 100 people among Central Asian countries (Table 2 and 3).

Table 2: The number of mobile cellular subscriptions per 100 people in Central Asia

\begin{tabular}{|c|c|c|c|c|}
\hline № & Country & in 2010 & in 2018 & in 2019 \\
\hline 1 & Kazakhstan & 118,3 & 146,6 & 139 \\
\hline 2 & Turkmenistan & 62,9 & 162,8 & 163 \\
\hline 3 & Kyrgyzstan & 97,3 & 121,9 & 134 \\
\hline 4 & Tajikistan & 77,7 & 111 & 112 \\
\hline 5 & Uzbekistan & 73,2 & 76 & 101 \\
\hline
\end{tabular}

Source: Prepared by the author based on data from the World Bank [9].

Table 3: The number of individuals using the Internet (\% of population) 


\begin{tabular}{|c|c|c|c|}
\hline № & Country & in 2010 & in 2018 \\
\hline 1 & Kazakhstan & 31,6 & 76,4 \\
\hline 2 & Uzbekistan & 15,9 & 55 \\
\hline 3 & Kyrgyzstan & 16,3 & 38 (in 2017) \\
\hline 4 & Tajikistan & 11,6 & 22 (in 2017) \\
\hline 5 & Turkmenistan & 3 & 21 (in 2017) \\
\hline
\end{tabular}

Source: Prepared by the author based on data from the World Bank [10].

This is due to several important factors that are interrelated and largely determine the specifics of Kazakhstan as a leader of digitalization in the region. The above statistical facts and data show that digitalization is a general trend for the countries of the Central Asia region, where there is an increase in the number of mobile phone users and Internet access among the population. Obviously, from the technical point of view, digitalization in Kazakhstan has no difficulties and limitations, since there is a high percentage of the population with access to the Internet and mobile phones.

First of all, the spread of digital technologies is one of the state priorities, and they are given a lot of place in government programs. So, since 2017, the State Program "Digital Kazakhstan" has been implemented, according to which very ambitious goals are set to develop increasing Internet access to $82 \%$ by 2020 [11]. The role of the government in the development of digital technologies in Kazakhstan is rather ambiguous and controversial. On the one hand, the Digital Kazakhstan program includes various projects for the allocation of state grants and activities for the development of digitalization in the country until 2022. However, the Program ignored the important sphere of communication and the impact of digitalization on the processes of democratization, increasing openness, accountability, and transparency of the work of state authorities. The content analysis of the Program showed that the term "democracy" was used only once and only in the sense of improving environmental protection among the "Creating a "Unified State System for Monitoring the Environment and Natural Resources" will allow in the political and legal aspect: to contribute to the implementation of the national sustainable development strategy and environmental disaster prevention; contribute to the implementation of publicity and democratization processes in the field of environmental protection and natural resources; create the necessary conditions for access for the general public to environmental information resources; to monitor public opinion on environmental issues" [11]. In general, digitalization in Kazakhstan is recognized as the main mechanism for the long-term development of the state, society and economy, which was confirmed in the Strategic Development Plan of the country until 2025 from 2018. The strategy includes a "roadmap" for the implementation of the digitalization program in education, civil service, government, in the field of economics, developing the theory of "digital bureaucracy". The strategy showed that the priority of digitalization in the field of politics and public administration is the technical development of the bureaucratic system, the fight against corruption, increased accountability of civil servants, the strengthening of the rule of law, the judicial system without attention to another important elements of the development of democracy such as a multi-party system, elections of local and central authorities, protection of political rights of citizens [12].

There is a unique initiative of the new President of Kazakhstan K. Tokayev within the framework of the "Hearing state" concept, which has become an answer to many questions of the development of digitalization in the political sphere and the prospects for "digital democracy". It presented many promising and revolutionary plans and tasks for Kazakhstan, such as the notification character of holding, organizing peaceful rallies; the development of a multi-party system and the encouragement of open political competition; support for the work of human rights organizations, civil and political activists. For the first time, the Head of State, in his message to the people of the country in 2020, spoke for the need to digitize the process of discussing reforms and proposals from the population, public organizations through online petitions and appeals [13]. However, according to opinion and position of international human rights organizations like "Human Wright Watch", the digitalization of the political sphere in Kazakhstan is limited to elements and projects of "digital bureaucracy" [14]. According to the position of Freedom House, the ongoing programs of 
democratization, protection of the political rights of citizens, permission of the organization, obtaining permission for peaceful rallies through digitalization of the political process have only a formal declaration without real impact on changes in the nature of relations between the government and civil society, the media, opposition movements [15].

In comparison to neighboring countries of the region, Uzbekistan has been developing the State Program "Digital Uzbekistan 2030", however, this program does not have a roadmap for implementation and clear realization of exact goals. Moreover, according to the statement of the Head of the country, Shavkat Mirziyoyev, the digitalization process should be focused on economic goals without special attention and connection with the political transformation of the functions of central and local authorities, the development of digital media, social networks [16]. In 2018, the National Development Strategy of the Kyrgyz Republic for 2018-2040 was adopted, in which promising directions and tasks of the future digital transformation of the country were noted. Currently, there is only the Digital Transformation Concept "Digital Kyrgyzstan 2019-2023", which indicated the priority tasks for the initial stage of the implementation of the promising goal of digitalization of the country. The state document confirms that the Kyrgyz Republic has prospects and opportunities to become a participant in the development of digital technologies, which will determine the future development of the country and the whole society. The positive side of the Concept is the recognition of the connection and interdependence between economic development, public administration, the quality of public services, the business climate and the activity of people [17].

An important issue in studying the impact of digital technologies on political processes in Central Asia is the issue of freedom of distribution and information in the Internet, access to opposition media channels, non-governmental news websites, and the ability of political activists to disseminate and receive politically, socially significant information. Despite the fact that Kazakhstan has an open and transparent policy regarding the use of means of communication by the population, compared with Uzbekistan and Turkmenistan, all Central Asian countries were classified as "not free" according to the results of 2018, by the non-governmental organization Freedom House, except Kyrgyzstan, which was recognized as "partly free" [15]. The following were identified as the main negative factors affecting the low position of Kazakhstan among the countries of the region: "authorities prosecuted internet users for "extremism," while online outlets Ratel.kz and Forbes Kazakhstan were charged for disseminating false information via articles detailing a former government official's alleged corrupt business dealings... - new amendments to the law on information and communications restricted anonymity online by mandating that website commentators register... - The National Security Committee took control of the State Technical Service and has been given more power over online content and ICT infrastructure..." [18].

A special example of the influence of social networks, the Internet in Central Asia is shown by Kyrgyzstan. In terms of the penetration of social networks into the political sphere of the struggle for power between parties, between political leaders, for the dissemination of political information and the involvement of the population, Kyrgyzstan is a unique example among the countries of the region. In this country, the influence of social networks has led to an increase in the political culture of the population, the free flow of information, but at the same time brought the masses of people to the revolution and caused great casualties among the civilian population [19]. A particular example and the situation can be argued for various reasons for the economic and social problems of Kyrgyzstan, but it is obvious that such prospects for revolutionary changes for some other Central Asian countries can be disastrous in terms of maintaining independence, territorial integrity and the peaceful end of such political conflicts.

So, until 2018, the leadership of Uzbekistan took tough measures to control information in their country, including hindering the penetration level of mobile communications and the Internet, justifying this with the technical problems of providers and the cultural characteristics of society [20]. The situation with social networks in Uzbekistan is undergoing dramatic changes in connection with the new policy of the country's authorities in relation to the Internet space, the activities of the current President of the country Shavkat Mirziyoyev and the pressure of the population, active in the digital 
space on the socio-political processes in the country. At the state level, the overwhelming influence of social networks, the process of digitalization of the information space in the political and public sphere, where it is impossible to hide the political, socio-economic problems of society and the state, is recognized by senior officials of Uzbekistan. According to Komil Alimjonov, Head of the Information and Mass Media Agency, social networks were previously blocked due to technical reasons and by the decision of influential people of the country who decided in such a simple way to deal with negative messages and information in the network [21]. A positive tendency of Uzbekistan in the digitalization of the country is the recognition of the need to use and develop new methods of propaganda, the dissemination of official information, as a counterargument and appeal by facts. Such processes and the situation in present-day Uzbekistan can be recognized as revolutionary, when the need to transform the attitude of state bodies to social networks and to modernize the role of the state in disseminating and promoting official information in the same ways and methods used in the Internet is recognized. However, it can be highlighted that the changes are taking place not only due to a rational understanding of the strength and influence of social networks, but also as a result of pressure and demands from below, when the population itself finds ways to unblock social networks, unblock access to inaccessible Internet sites by using VPN addresses and other technical capabilities. With regard to modern processes in Uzbekistan, it is necessary to stop separately and note that the country is beginning to make big changes and transformations in the economy, politics, public administration, as well as in the field of digitalization, the Internet space. At present, it is difficult to draw final conclusions about the direction of further modernization and reform of the state, the processes of changing civil society and democratization in general. The coming years will become important for the long-term future of Uzbekistan, which may become the leader in development, modernization and transformation in Central Asia, or remain in the position of an outsider in the region, which had all the opportunities and resources to take the lead in Central Asia. Turkmenistan remains a closed country where there is no reliable information on the socio-economic situation of the country's population, not to mention the digitalization process and the development of digital social communications. Tajikistan, like Turkmenistan, in 2021 remains the only countries in the region where there is even no single Concept and adopted medium-term state programs for digital development of the country, the attitude of government bodies to the most important process that separates developing countries from the international community and the global economic process.

An even more important factor influencing the increase in the digitalization process is the developing economy, which has led to an increase in the population's demand for such services and products. The purchasing power of citizens of Kazakhstan for decades has been higher than in other countries of Central Asia, and continues to be higher until now. This led to higher growth rates in the acquisition of various digital gadgets and communication services than in Kyrgyzstan and Tajikistan, which are comparatively comparable in terms of freedom with Kazakhstan. Therefore, the trends of the impact of digital technologies on sociopolitical processes manifested themselves most clearly and precisely in Kazakhstan, allowing us to see what lines social development could take in the region, taking into account the indicated factors. One of these lines is a change in the social structure of society, under the influence of digital technology. Naturally, all the traditional contours are preserved, but this complicates the structure. This is due to conditional differentiation between the so-called "Virtual Kazakhstan" and real Kazakhstan, where the first plays the role of a certain managerial superstructure, while the second is the basis receiving impulses from the first.

\section{Discussion}

In studying the process and achievements of digitalization in Kazakhstan, it is important to note that the process is not unambiguous and uniform for the whole society in the country, in conditions of different levels of use, understanding of the mechanisms of work and the possibilities of electronic communication technologies. It is obvious that there are different social, age, economic groups of the population that are the main consumers of digital technologies, which distinguishes them as objects, actors, initiators of the digitalization of political relations in Kazakhstan. In many ways, the differences between social groups are determined by the so-called "digital divide", knowledge, experience, skills in using digital information and communication technologies. The majority of 
Kazakhstanis still represent a significant group of the population, who most often act as a passive audience, absorbing information and ideological clichés imposed on them. For them, digitalization is limited only to obtaining certificates necessary for employment, business, education or social donations from the government. They are active consumers of digital services and are limited to the provided services and functions of state digital projects "electronic government", "digital Kazakhstan". However, "virtual Kazakhstan" today is represented by a new, growing group of population, who are active users of functions, services of "electronic government" and actively express their position, opinion not only in official, government media blogs or official pages of the leaders of Kazakhstan, but also in social networks. Thanks to information skills, experience, having access to information resources, they can shape the political agenda themselves. In the conditions of rapid economic growth, characteristic of Kazakhstan several years ago, this social stratum had a high level of legitimation in the mass consciousness, was associated with success and was a reference (model) group for the entire society. This population group actively expresses its opinion and spread it through posts, publications and comments. And the third category is those who manage the entire communication process as a whole, understand all the features of the information space of Kazakhstan, have all the leverage of the media. Here it is necessary to make a digression, noting that there are very few representatives of the third category, they try not to show themselves in public space. In addition, this category is largely included by the so-called "old elite," made up of the leaders of the Soviet partocracy and their successors, who were able to privatize the industrial potential left over from the previous era and increase their wealth in the post-Soviet period. Naturally, the "old elite", fearing to lose their position and power, is making every effort to maintain the status quo, including by controlling the dissemination of information. The most negative scenario in this case is the contours of "informational totalitarianism", although now it seems incredible, given the modern openness of society and the resistance to such attempts on the part of civil activists. On the positive side, it can be noted that digital communication technologies ultimately bring to the forefront those groups that are more actively using all the possibilities of digital technologies, especially social networks. The accelerated dynamics of the implementation of political acts leads to the emergence of new groups of influence, which, figuratively speaking, become the "masters of the minds" of the population. This is a narrow layer of bloggers, writers and journalists who, through social networks, reach a wide audience. Along with the growth of digitalization, the spread and access to the mobile Internet, processes began when the functions of public protection of the interests of the population were taken over by social networks, which also became available to the majority of the population. They have begun to perform some functions or have replaced the activities of traditional opposition media and political parties. The most famous example is the digital activity of the illegal political organization "Democratic Choice of Kazakhstan", which exists exclusively virtually, in social networks and telegram channels, and does not require formal membership. In March 2018, the judicial system of Kazakhstan recognized the activities of the unregistered movement "Democratic Choice of Kazakhstan" illegal and extremist, and the founder and leader of the organization was sentenced in absentia to 20 years in Kazakhstan. An illegal organization through social networks, messengers actively encourages citizens to join the organization, forms a negative image of the current government and provokes protest moods, thereby systematically inciting social hatred and discord. According to the Law of Kazakhstan "On Counteracting Extremism", political extremism is considered a crime against state security. Participation in the work of a prohibited movement, financing and promotion of its work are prosecuted in accordance with the Criminal Code of Kazakhstan [22].

But still, the main thing is that social networks, primarily Facebook, turned into political dialogue and discussion platforms, where alternative public opinion began to be expressed, and on the widest range of issues, from ecology to constitutional reform, from hunger in Kazakhstan 19321933 to women's rights and the LGBT community. Initially, government bodies ignored such activity, since, on the one hand, they did not consider them to be of any significance. Indeed, the Facebook community of Kazakhstan in 2011 amounted to less than 300,000 people [23], which was negligible, although qualitatively these users exceeded the audience of other social networks popular 
then in Kazakhstan (VKontakte, My World, Odnoklassniki), albeit losing quantitatively, as they systematically developed political themes. In addition, the inertia of the bureaucracy affected, which has not yet formed protocols for responding to the activity of the population in social networks, and also has not developed mechanisms for perceiving such information. Despite the proclaimed programs of "Governments for Citizens", their essence was seen exclusively in the issuance of population certificates in electronic form, without taking into account the political activity of the population in virtual reality.

The situation changed in 2014, after the Ukrainian events that stirred up the social networks of Kazakhstan. The annexation of Crimea by Russia, the hostilities in the Donetsk and Lugansk regions of Ukraine caused fierce battles in the Kazakhstani segment of social networks, between supporters of pro-Russian and pro-Ukrainian orientation. In fact, the society turned out to be divided on a number of ideological and political issues, and it was precisely on social networks, although some common unity was officially doctrinated on the primacy of Kazakhstan citizenship. According to the opinion of a group of scientists drawing parallels between Ukraine, Armenia and the countries of Central Asia [24], there are negative prospects for the growth of instability, the emergence of mass actions of discontent in the countries of the post-Soviet space due to the increase in digitalization, the growth of politicization of social networks, the penetration of the Internet into the sphere of political relations in the absence of effective mechanisms for the government to respond to the wishes and opinions of the population.

The danger of increased tension and instability in the countries of Central Asia due to the growth and influence of social networks, dissemination of political information via digital technologies, including radical information, is confirmed by modern studies. According to studies by a group of scientists [25] in political regimes where traditional media are controlled by the state, social networking sites may be the only place where citizens encounter and exchange information to express their political discontent. The technical and professional backwardness and inefficiency of the state and special internal affairs bodies of Central Asian countries, the inability to effectively limit the radicalization of social networks and the Internet, can lead to the expansion of the functions of social networks as a digital mechanism and a resource of political instability in the countries of the region. Moreover, lack of readiness of the government to propose other methods of information warfare against the radicalization of social networks, to propose a different opinion on social networks can undermine the credibility of state and official information, undermine the trust and legitimacy of local authorities and government. In turn, a decline in confidence can stimulate protest behavior, which is already high and is aggravated by the social, economic problems that are present in all countries of Central Asia. The issue of professional training and advanced preparation of officials, special government agencies in the information sphere, the Internet space determines the need to change the public service system itself, the transformation of the functions of government agencies, as the main mechanism to increase confidence to official media, state or governmentcontrolled social networks.

Research results.

Modern facts and processes in Kazakhstan prove that there is a complex process of choosing the country's authorities in relation to social networks, Internet media, and in general to the process of politicization of the Internet space. Top management represented by President Tokayev and former deputy chairman of the lower house of the Parliament of Kazakhstan Dariga Nazarbayeva promote two different points of view regarding the problem of controlling the management of the politicization of social networks and the politicization of the Internet space [26]. The discussion and possible adoption of a new law on limiting the work of world social networks, the requirements for their registration in Kazakhstan shows the desire of the Kazakh authorities to regulate and establish the boundaries of the work of social networks in the country.

\section{Conclusion.}

Thus, digitalization is a multifaceted and complex process that takes place in many areas of state, social development, economy and business in Kazakhstan with a growth and deepening trend. Currently, the digitalization of the political sphere of Kazakhstan is just beginning and has different 
directions for further development. State policy has various programs such as "e-government", "Hearing state", which aim to digitalize many processes of public service, economic relations, trade, business. The digitalization of the political sphere in Kazakhstan is limited by the principles of "digital bureaucracy" with possible prospects and elements of "digital democracy" in accordance with the plans and the "Hearing State" project. It is difficult to assess the further development of digitalization in Kazakhstan and in the countries of the Central Asian region, since they have different speeds and tasks without communication with each other. It is especially difficult to assess the impact of digitalization on the political sphere of Kazakhstan, since it is obvious that digitalization in the political sphere will be limited and will not affect many elements, examples of political digitalization described in the theories of political transformation. However, it is obvious that digitalization as a large-scale and difficult to control process will increase the digital activity of the population, especially among young people, and it will be difficult or impossible to control the growth of political activity of various organizations and movements, including radical and extremist ones, by simple restrictions and prohibitions. The growth of digital activity, digital literacy in the field of social relations in the country will inevitably raise the question of the further development of digitalization in the political sphere in the near future. Digitalization will also require advanced training of civil servants themselves to meet the requirements of the time and the requirements of politically active citizens, political parties, social movements, which will also increase their activity in the digital sphere.

\section{References}

1. Konkov A.E. Digitalization in political relations: planes for perception and mechanisms for transformation. Global Infrastructure in the Digital Age // The contours of global transformations: politics, economics, law. - 2019 -№12(6). -P.6-28. (In Russ.) - DOI:10.23932/2542-0240-2019-126-1

2 Hanna N. A role for the state in the digital age // Journal of Innovation and Entrepre-neurship. -2018. - №7. -P.1-16. DOI: 10.1186/s13731-018-0086-3

3. Dommett K., Kefford G. and Power S. The digital ecosystem: the new politics of party organization in parliamentary democracies // Party Politics. -2020.-February. -P. 1-11. DOI: $10.1177 / 1354068820907667$

4. Coleman S. Can the internet strengthen democracy? // European Journal of Communication. -2018. -№33. -P.461. DOI: https://doi.org/10.1177/0267323118789517a

5. Digital technologies in combating corruption focus of OSCE high-level regional conference in Almaty. OSCE Secretariat, Communication and Media Relations Section [Data file]. -2021. - URL: https://www.osce.org/secretariat/435020 (retrieved 03.07.2021)

6. Digital Adoption Index. The World Bank. [Data file]. - 2021. - URL: https://www.worldbank.org/en/publication/wdr2016/Digital-Adoption-Index (retrieved 03.07.2021)

7. Corruption perception index. Transparency International INGO [Data file]. -2021. - URL: https://www.transparency.org/en/cpi/2020/index/usa

8. World digital competitiveness index. Institute for Management and Development [Data file]. 2021. - URL: https://www.imd.org/centers/world-competitiveness-center/rankings/ (retrieved 03.07.2021)

9. Mobile cellular subscriptions per 100 people. The World Bank. [Data file]. -2021. - URL: https://data.worldbank.org/indicator/IT.CEL.SETS.P2 (retrieved 03.07.2021)

10. Individuals using the Internet (\% of population). The World Bank. [Data file]. -2021. - URL: https://data.worldbank.org/indicator/IT.NET.USER.ZS

11. State Program "Digital Kazakhstan". Decree of the Government of the Republic of Kazakhstan No. 827 [Data file]. -2017. -URL: http://egov.kz/cms/ru/law/list/P1700000827 (retrieved 03.07.2021)

12. Strategic plan 2025. Official informational resource of prime-minister office of the RK. [Data file]. -2018. -URL: https://primeminister.kz/ru/documents/gosprograms/stratplan-2025 (retrieved 03.07.2021) 
13. Message from the Head of State Kassym-Zhomart Tokayev to the people of Kazakhstan: Kazakhstan in a new reality: time for action. Official web site of the President of Kazakhstan. [Data file]. -2020. - URL: https://www.akorda.kz/ru/addresses/addresses_of_president/poslanie-glavygosudarstva-kasym-zhomarta-tokaeva-narodu-kazahstana-1-sentyabrya-2020-g

14. Kazakhstan: crackdown on government critics. The human rights watch organization. [Data file]. -2021. - URL: https://www.hrw.org/news/2021/07/07/kazakhstan-crackdown-governmentcritics

15. Nations in transit: Kazakhstan. Freedom house organization. [Data file]. -2020. - URL: https://freedomhouse.org/country/kazakhstan/nations-transit/2020

16. Mirziyoyev: Uzbekistan planiruet dovesti dolu cifrovoi economiki do 30\% (Mirziyoyev: Uzbekistan plans to increase the share of the digital economy to 30\%). Sputnik Uzbekistan news agency. [Data file]. -2019. -URL: https://uz.sputniknews.ru/economy/20181228/10368929.html (retrieved 03.07.2021)

17. Digital Kyrgyzstan. National digital transformation Concept. Government of the Kyrgyz Republic [Data file]. - 2019. -URL: https://digital.gov.kg/(retrieved 03.07.2021)

18. Freedom on the Net 2018. Washington, DC: Freedom House. [Data file]. -2018. -URL: https://freedomhouse.org/report/freedom-net/freedom-net-2018 (retrieved 03.07.2021)

19. Turdubaeva E. Communicating with voters in social networks: the case of 2011 Presidential elections in Kyrgyzstan // Mediterranean Journal of social sciences. - 2013. - \#4(9). -P.482-493.URL:DOI: 10.5901/mjss.2013.v4n9p482

20. "Mi dazhe ne mechtali!" V Uzbekistane razblokirovali saiti, kritikovavshie vlasj ("We didn't even dream!" Sites that criticized the government have been unblocked in Uzbekistan). BBC news agency. [Data file]. - 2019. -URL: https://www.bbc.com/russian/features-48284122 (retrieved 03.07.2021)

21. Altman K. Blokirovavshich Facebook $i$ YouTube v Uzbekistane posadili v turmu - Komil Allamzhanov (Facebook and YouTube blockers put in jail in Uzbekistan - Komil Allamzhanov). CA news agency. [Data file]. - 2019. -URL: http://ca-news.org/news:1560216 (retrieved 03.07.2021)

22. Mukanov B. Partia Ablyazova DVK priznana extremistskoi organizatsiei v Kazakkhstane (Party of Ablyazov DCK recognized as extremist organization in Kazakhstan). Informburo.kz. news agency. [Data file]. -2019. -URL: https://informburo.kz/novosti/partiyu-ablyazova-dvk-priznaliekstremistkoy-organizaciey-v-kazahstane-.html (retrieved 03.07.2021)

23. Kazakhstan is nearing No.100 in Facebook. Tengrinews.kz. news agency. [Data file]. -2019. -URL: https://en.tengrinews.kz/internet/Kazakhstan-is-nearing-No100-in-Facebook-95/ (retrieved 03.07.2021)

24. Brodovskaya E., Dombrovskaya A. and Karzubov D. Online mobilization of mass protests in Ukraine, Moldova, Armenia, and Kazakhstan (2013-2016.): the results of comprehensive comparative empirical. International conference on electronic governance and open society in Eurasia (EGOSE 2017).-2017.- P.32-36. -URL: $\quad$ DOI: $10.1145 / 3129757.3129764$ (retrieved 03.07.2021)

25. Bekmagambetov A., Wagner K.M., Gainous J., Sabitov Z., Rodionov A. and Gabdulina B. Critical social media information flows: political trust and protest behaviour among Kazakhstani college students // Central Asian survey. -2018. -\# 37(4). -P.526-545. -URL: DOI: 10.1080/02634937.2018.1479374

26. Orazbaieva A. Dariga Nazarbaieva: "Globalnaia infosreda neset ugrozu suvereitetu” (in Russian language) // Newtimes.kz news agency. [Data file]. -2021. -URL: https://newtimes.kz/obshchestvo/136431-dariga-nazarbaeva-globalnaia-informatsionnaia-sredaneset-ugrozu-suverenitetu (retrieved 18.09.2021)

\section{Spisok ispolzovannich istochnikov}

1. Konkov A.E. Tcifrovizatsia politicheskich otnosheni: grani poznania I mechanimi transformatcii. // Konturi globalnich transformatci: politika, economika, pravo. - 2019 -№12(6). P.6-28. - DOI:10.23932/2542-0240-2019-12-6-1 
2 Hanna N. Rol gosudarstva v cifrovuiu epochu // Journal of Innovation and Entrepre-neurship. -2018. - №7. -P.1-16. DOI: 10.1186/s13731-018-0086-3

3. Dommett K., Kefford G. and Power S. Tcifrovaia ekosistema: novaia politika poiticheskoi transformatcii v parlamentskich demokratiach // Party Politics. -2020.-February. -P. 1-11. DOI: 10.1177/1354068820907667

4. Coleman S. Mozhet li internet usilit demokratiu ? // European Journal of Communication. 2018. -No33. -P.461. DOI: https://doi.org/10.1177/0267323118789517a

5. Cifrovie technologii v borbe s korrupciei mnenie OBCE v visokoi konferencii v Almate. OSCE Secretariat, Communication and Media Relations Section [Data file]. -2021. - URL: https://www.osce.org/secretariat/435020 (retrieved 03.07.2021)

6. Indeks Tcifrovogo Vospriatia. The World Bank. [Data file]. - 2021. - URL: https://www.worldbank.org/en/publication/wdr2016/Digital-Adoption-Index (retrieved 03.07.2021)

7. Indeks Vospriatia Korruptcii. Transparency International INGO [Data file]. -2021. - URL: https://www.transparency.org/en/cpi/2020/index/usa

8. Indeks Mirovoi cifrovoi Konkurentosposobnosti. Institute for Management and Development [Data file]. -2021. - URL: https://www.imd.org/centers/world-competitiveness-center/rankings/ (retrieved 03.07.2021)

9. Podpiski na mobil'nuyu sotovuyu svyaz' na 100 chelovek. The World Bank. [Data file]. -2021. - URL: https://data.worldbank.org/indicator/IT.CEL.SETS.P2 (retrieved 03.07.2021)

10. Fizicheskiye litsa, pol'zuyushchiyesya Internetom (\% naselenia). The World Bank. [Data file]. -2021. - URL: https://data.worldbank.org/indicator/IT.NET.USER.ZS

11. Gosudarstvennaia Programma "Tcifrovoi Kazahstan". Decree of the Government of the Republic of Kazakhstan No. 827 [Data file]. -2017. -URL: http://egov.kz/cms/ru/law/list/P1700000827 (retrieved 03.07.2021)

12. Strategicheski Plan 2025. Ofitsial'nyy informatsionnyy resurs apparata Prem'yer-Ministra RK. [Data file]. -2018. -URL: https://primeminister.kz/ru/documents/gosprograms/stratplan-2025 (retrieved 03.07.2021)

13. Poslaniye Glavy gosudarstva Kasym-Zhomarta Tokayeva narodu Kazakhstana: Kazakhstan v novoy real'nosti: vremya deystvovat'. Ofitsial'nyy sayt Prezidenta Kazakhstana. [Data file]. -2020. - URL: https://www.akorda.kz/ru/addresses/addresses_of_president/poslanie-glavy-gosudarstvakasym-zhomarta-tokaeva-narodu-kazahstana-1-sentyabrya-2020-g

14. Kazakhstan: podavleniye kritikov pravitel'stva. Organizatsiya po zashchite prav cheloveka. [Data file]. -2021. - URL: https://www.hrw.org/news/2021/07/07/kazakhstan-crackdowngovernment-critics

15. Narod v puti: Kazakhstan. Organizatsiya Freedom House. [Data file]. -2020. - URL: https://freedomhouse.org/country/kazakhstan/nations-transit/2020

16. Mirziyoyev: Uzbekistan planiruet dovesti dolu cifrovoi economiki do 30\%. Sputnik Uzbekistan news agency. [Data file]. -2019. https://uz.sputniknews.ru/economy/20181228/10368929.html (retrieved 03.07.2021)

17. Tsifrovoy Kyrgyzstan. Kontseptsiya natsional'noy tsifrovoy transformatsii. Pravitel'stvo Kyrgyzskoy Respubliki [Data file]. - 2019. -URL: https://digital.gov.kg/(retrieved 03.07.2021)

18. Svoboda v seti 2018. Washington, DC: Freedom House. [Data file]. -2018. -URL: https://freedomhouse.org/report/freedom-net/freedom-net-2018 (retrieved 03.07.2021)

19. Turdubaeva E. Obshcheniye s izbiratelyami $v$ sotsial'nykh setyakh: keys prezidentskikh vyborov 2011 goda v Kyrgyzstane // Mediterranean Journal of social sciences. - 2013. - \#4(9). P.482-493.-URL:DOI: 10.5901/mjss.2013.v4n9p482

20. "Mi dazhe ne mechtali!" V Uzbekistane razblokirovali saiti, kritikovavshie vlasj. BBC news agency. [Data file]. - 2019. -URL: https://www.bbc.com/russian/features-48284122 (retrieved 03.07.2021)

21. Altman K. Blokirovavshich Facebook i YouTube v Uzbekistane posadili v turmu - Komil Allamzhanov. CA news agency. [Data file]. - 2019. -URL: http://ca-news.org/news:1560216 (retrieved 03.07.2021) 
22. Mukanov B. Partia Ablyazova DVK priznana extremistskoi organizatsiei v Kazakkhstane. Informburo.kz. news agency. [Data file]. -2019. -URL: https://informburo.kz/novosti/partiyuablyazova-dvk-priznali-ekstremistkoy-organizaciey-v-kazahstane-html (retrieved 03.07.2021)

23. Kazakhstan priblizhayetsya $k$ 100-y strochke v Facebook. Tengrinews.kz. news agency. [Data file]. -2019. -URL: https://en.tengrinews.kz/internet/Kazakhstan-is-nearing-No100-inFacebook-95/(retrieved 03.07.2021)

24. Brodovskaya E., Dombrovskaya A. and Karzubov D. Onlayn-mobilizatsiya massovykh protestov v Ukraine, Moldove, Armenii i Kazakhstane (2013-2016 gg.): Rezul'taty kompleksnogo sravnitel'nogo empiricheskogo analiza. Mezhdunarodnaya konferentsiya po elektronnomu upravleniyu i otkrytomu (EGOSE 2017).-2017.- P.32-36. -URL: DOI: 10.1145/3129757.3129764 (retrieved 03.07.2021)

25. Bekmagambetov A., Wagner K.M., Gainous J., Sabitov Z., Rodionov A. and Gabdulina B. Kriticheskiye informatsionnyye potoki $v$ sotsial'nykh setyakh: politicheskoye doveriye $i$ protestnoye povedeniye kazakhstanskikh studentov // Central Asian survey. -2018. -\# 37(4). -P.526-545. -URL: DOI: 10.1080/02634937.2018.1479374

26. Orazbaieva A. Dariga Nazarbaieva: "Globalnaia infosreda neset ugrozu suvereitetu" // Newtimes.kz news agency. [Data file]. -2021. -URL: https://newtimes.kz/obshchestvo/136431dariga-nazarbaeva-globalnaia-informatsionnaia-sreda-neset-ugrozu-suverenitetu (retrieved 18.09.2021) 